\title{
Comparative Study of Performance Test of Refrigerators and Its Relationship with Electric Power Consumptions
}

\author{
Arwizet Karudin \\ Jurusan Teknik Mesin, Fakultas Teknik, Universitas Negeri Padang, Indonesia
}

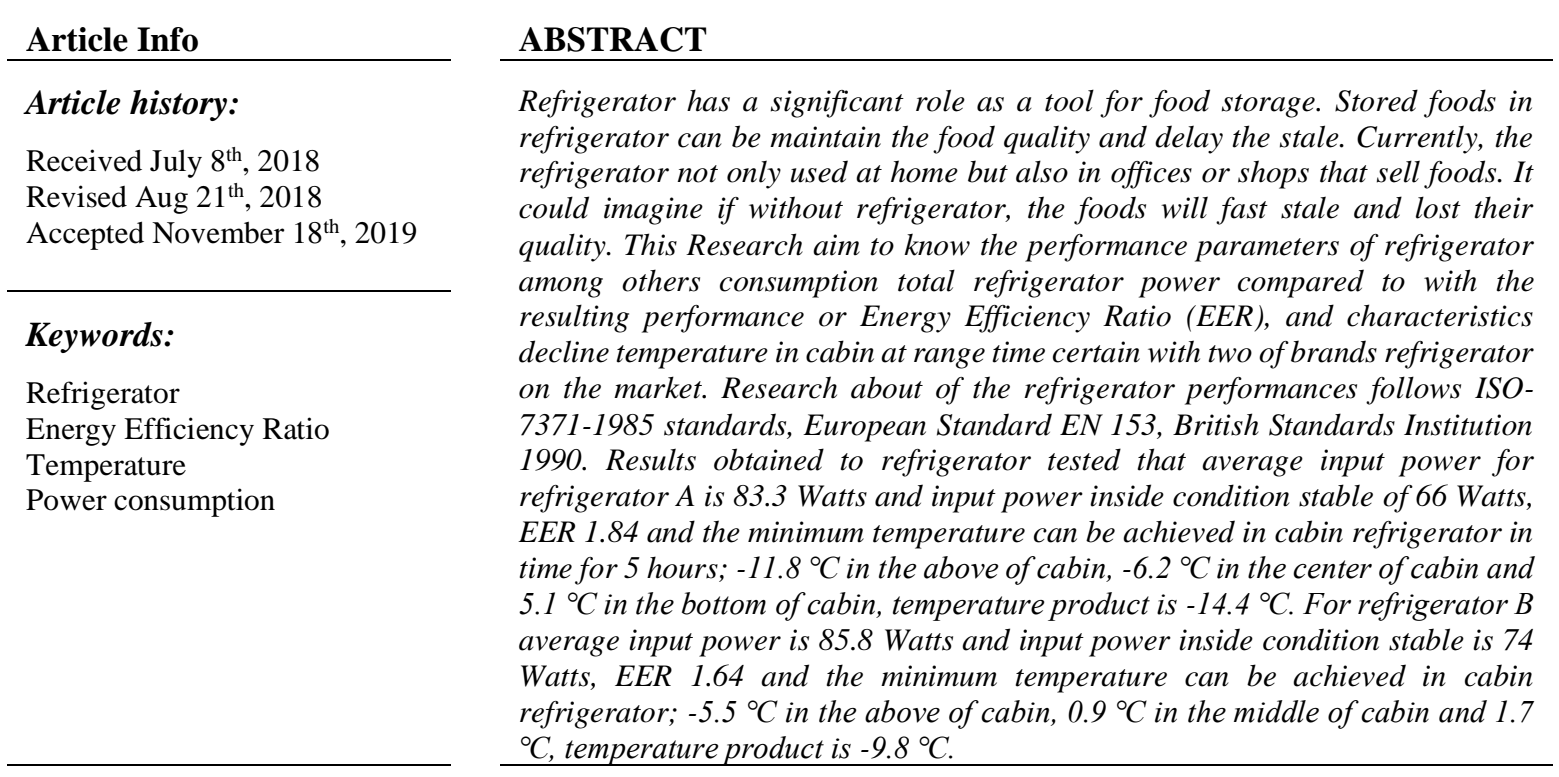

\section{Corresponding Author:}

Arwizet Karudin,

Jurusan Teknik Mesin, Fakultas Teknik, Universitas Negeri Padang

Jln. Prof. Dr. Hamka Air Tawar, Padang (25131), Sumatera Barat, Indonesia

Email: arwizet1969@gmail.com

\section{INTRODUCTION}

Refrigerator is a cabinet that have cold temperatures function for cool or preserve products included to inside so as not to fast broken or stale. Refrigerator have many functions could use for storage meat, fish, eggs, food cans, fruits and vegetables. Refrigerators much found its usage such as in supermarkets and in places sale of juice and ice cream, in offices and at household. Form physical refrigerator encountered also vary corresponding with location usage and function for what he used. If used for storage meat or fish, the refrigerators named after with frozen, storage ingredients or product in called long-term with cold storage, which is used in supermarkets for fruits, vegetables, food/ drinks cans, eggs and known with display case [1]. Refrigerators used for household have form different with those used in supermarkets. Refrigerators for household generally shaped simpler and size smaller and be equipped with some cabin for storage meat/ fish, storage eggs and products food/ drink cans and cabins for storage vegetables.

Refrigerator in principle is an equipment household in need power electricity. Use power small electrical certain very profitable for consumer user refrigerator. Refrigerator with show off good work, achievement temperature in a low cabin and save electricity considered refrigerator with good performance. On the market many the brand refrigerator encountered issued by various companies. Each stated that product they are good and economical electricity. The amount product refrigerator issued by company make consumer confusion in choose and determine the brand which refrigerator is good used at household. this certain reviewed from ability refrigerator that is bring down temperature stored products, power electricity needed and efficiency of the refrigerator system in a manner general Energy Efficiency Ratio (EER). Research this aiming for knowing performance parameters refrigerator among others consumption total refrigerator power compared to with the resulting performance or EER, characteristics decline temperature in cabin in range time certain and input power needed. From the results research this expected obtained picture comparison parameter two the brand 
refrigerator tested; refrigerator brand A and refrigerator B. brand for research next could developed to some the brand trade refrigerator others.

According to Roy J. Dossat (1981) refrigerator divided on two categories; for freezing and for cooling. Refrigerator for freezing (frozen refrigerator) many used for ice cube maker, storage product in the form of meat, fish and some product others that are stored with way freezing so durable and long lasting. Rrefrigerators for cooling down (cooling refrigerator) many used for storage products that don not frozen as eggs, drinks and food cans, vegetables and fruits. Based on usage the refrigerator can also distinguish with refrigerator use in shops supermarket or office space its size. Second is refrigerator used at home are used for storage product. Type this generally room in cabin refrigerator distinguished again that is room for freezer and space for product not frozen as product cans, eggs, fruits and vegetables.

\section{METHOD}

Refrigerator testing were follow ISO-7371-1985 standard and the European Standard EN 153, British Standards Intitution, 1990. Refrigerator placed in something the rooms were kept temperature at temperature certain. The burden heat to refrigerator could constant in range certain time. Room testing refrigerator shaped room closed and isolated thermally. Size room testing this is $4 \mathrm{~m}$ long, $4 \mathrm{~m}$ wide and $2.5 \mathrm{~m}$ high. Temperature room always guarded in condition fixed $32{ }^{\circ} \mathrm{C}$ to meet standard testing refrigerator class tropical (ISO-73711985). To maintain temperature room at $32{ }^{\circ} \mathrm{C}$ was used heating room (electric heater) with a capacity of 750 - 2250 Watts and electric air conditioner with 1.5 HP power. Tool gauge temperature room used APPA51 digital thermometer with thermocouple type $\mathrm{K}$.

Measurement temperature in cabin refrigerator and product used thermocouple sensor type $\mathrm{K}$, which is connected to tool data logger (data recorder), made by Yokogawa with type 3081 Hybrid Recorder. Power electricity be measured use the Watt meter type E 3201 Willis brand that can measure power electricity, current electricity and voltage electricity enter to in refrigerator in a manner together. For product testing used water is inserted to in box measuring $5 \times 10 \times 20 \mathrm{~cm}$ and weighing $1 \mathrm{~kg}$. The energy absorbed by the evaporator inside cabin refrigerator should same with total the energy released by the product (from temperature early to freezes and arrives temperature end product), air in cabin refrigerator and heat entering to in refrigerator through wall the room.

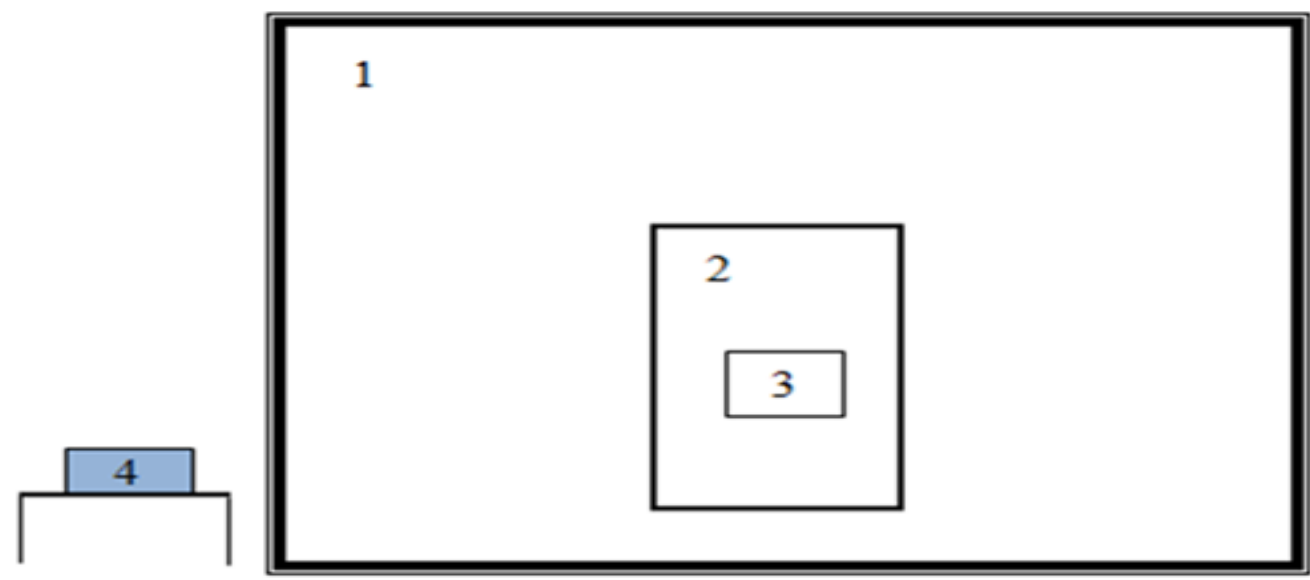

Annotation:

1. Cabin refrigerator

2. Refrigerator testing

3. Product testing

4. Data recorder

Figure 1 : Schematic of refrigerator testing

Cooling load on the refrigerator could distinguished on load the heat coming from product and load the heat coming from outside of the room. According to Roy J. Dossat (1981), the burden from outside of room distinguished. Something product at the time saved will have temperatures high than at temperature room refrigerator, so heat from product that is will absorbed by the evaporator which is located in room refrigerator. Result temperature product that is inserted in the refrigerator will same with temperature space in the cabin 
fridge and be load cooler that must be taken into account. Wall refrigerator are insulated ideally have construction capable inhibit hot conduction from outside of in system. But in reality, from considerations economical, consideration construction or condition air different environments in various the place cause load hot conduction from wall insulation permanent should take into account because could influence achievement work from refrigerator being tested. Transmission load that occurs in the refrigerator could through some part namely: a. Part wall above, b. Part wall back, c. Part wall side and part wall downstairs. Load transmission this could determine with use equation as the follows:

$$
\begin{aligned}
& \mathrm{Q}_{\mathrm{c}}=\mathrm{U} \cdot \mathrm{A} \cdot\left(\mathrm{T}_{\text {circle }}-\mathrm{T}_{\mathrm{r}}\right) \\
& \mathrm{Q}_{\mathrm{p}}=\mathrm{m} \cdot \mathrm{c}_{\mathrm{p}} \cdot\left(\mathrm{T}_{\mathrm{p}, \text { initial }}-\mathrm{T}_{\mathrm{p}, \text { end }}\right) \\
& Q_{p}=\frac{m_{a} \cdot\left[c_{p 1} \cdot\left(T_{\text {initial }}-0\right)\right]+h_{S f}+c_{p 2 \cdot(}\left(0-T_{\text {end }}\right)}{\tau} \\
& Q_{u}=\frac{m_{u} \cdot c_{\rho u} \cdot\left(T_{\text {initial }}-T_{\text {end }}\right)}{\tau}=\frac{\rho_{u} \cdot V_{u} \cdot c_{p u} \cdot\left(T_{\text {initial }}-T_{\text {end }}\right)}{\tau} \\
& \text { EER }=\frac{\text { Total Energy Absorbed by Evaporator }}{\text { Input Power to the Refrigerator }}=\frac{Q_{p}+Q_{u}+Q_{C}}{W_{\text {input }}}
\end{aligned}
$$

\section{RESULTS AND DISCUSSION}

Two type refrigerator tested that is A refrigerator and B refrigerator are obtained results as in tables 1 and 2 below:

Table 1. Made B Refrigerator Test Results Data Object Research

\begin{tabular}{|c|c|c|c|c|c|c|c|c|c|c|}
\hline No. & $\begin{array}{c}\text { Time } \\
(\mathrm{min})\end{array}$ & $\begin{array}{c}\text { Temp. } \\
\text { Cabin top } \\
\left({ }^{\circ} \mathrm{C}\right)\end{array}$ & $\begin{array}{c}\text { Temp. } \\
\text { Cabin } \\
\text { middle } \\
\left({ }^{\circ} \mathrm{C}\right)\end{array}$ & $\begin{array}{c}\text { Temp. } \\
\text { Cabin } \\
\text { bottom } \\
\left({ }^{\circ} \mathrm{C}\right)\end{array}$ & $\begin{array}{c}\text { Temp. } \\
\text { Products } \\
\left({ }^{\circ} \mathrm{C}\right)\end{array}$ & $\begin{array}{c}\text { Temp. } \\
\text { test } \\
\text { room } \\
\left({ }^{\circ} \mathrm{C}\right)\end{array}$ & $\begin{array}{c}\text { Current } \\
(\text { Amp })\end{array}$ & $\begin{array}{c}\text { Tense } \\
(\text { Volt })\end{array}$ & $\begin{array}{c}\text { Power } \\
(\text { Watts })\end{array}$ & EER \\
\hline 1 & 0 & 34.2 & 33.6 & 32.7 & 33.7 & 32.4 & 0.82 & 216 & 130 & 0.00 \\
\hline 2 & 30 & 14.4 & 15.2 & 17.2 & 15.1 & 32 & 0.781 & 218 & 128 & 0.66 \\
\hline 3 & 60 & 4.9 & 9.8 & 10 & 4.7 & 32.2 & 0.742 & 214 & 104 & 0.87 \\
\hline 4 & 90 & -0.1 & 5.4 & 5.6 & 1.1 & 32.2 & 0.718 & 216 & 96 & 0.96 \\
\hline 5 & 120 & $-3,1$ & 2.5 & 2.6 & 0.4 & 32.3 & 0.677 & 215 & 84 & 1.14 \\
\hline 6 & 150 & -4.7 & 0.4 & 0.9 & -2 & 31.7 & 0.675 & 216 & 82 & 1.55 \\
\hline 7 & 180 & -6.0 & -0.7 & -0.2 & -4.5 & 31.8 & 0.675 & 213 & 86 & 1.45 \\
\hline 8 & 210 & $-7,1$ & $-1,7$ & $-1,1$ & -7 & 32.8 & 0.675 & 213 & 74 & 1.64 \\
\hline 9 & 240 & $-8,5$ & -2.8 & -2.2 & -10.7 & 31 & 0.671 & 212 & 75 & 1.54 \\
\hline 10 & 270 & -10.1 & -4.4 & -3.2 & -12.7 & 31.9 & 0.650 & 212 & 74 & 1.62 \\
\hline 11 & 300 & -11.8 & -6.2 & -5.1 & -14.4 & 32.1 & 0.650 & 212 & 70 & 1.73 \\
\hline
\end{tabular}

Table 2. Made B Refrigerator Test Results Data Object Research

\begin{tabular}{|c|c|c|c|c|c|c|c|c|c|c|}
\hline No. & $\begin{array}{c}\text { Time } \\
(\mathrm{min})\end{array}$ & $\begin{array}{c}\text { Temp. } \\
\text { Cabin } \\
\text { top } \\
\left({ }^{\circ} \mathrm{C}\right)\end{array}$ & $\begin{array}{c}\text { Temp. } \\
\text { Cabin } \\
\text { middle } \\
\left({ }^{\circ} \mathrm{C}\right)\end{array}$ & $\begin{array}{c}\text { Temp. } \\
\text { Cabin } \\
\text { bottom } \\
\left({ }^{\circ} \mathrm{C}\right)\end{array}$ & $\begin{array}{c}\text { Temp. } \\
\text { Products } \\
\left({ }^{\circ} \mathrm{C}\right)\end{array}$ & $\begin{array}{c}\text { Temp. } \\
\text { test } \\
\text { room } \\
\left({ }^{\circ} \mathrm{C}\right)\end{array}$ & $\begin{array}{c}\text { Current } \\
(\text { Amp })\end{array}$ & $\begin{array}{c}\text { Tense } \\
(\text { Volt })\end{array}$ & $\begin{array}{c}\text { Power } \\
(\text { Watts })\end{array}$ & EER \\
\hline 1 & 0 & 32.8 & 32.8 & 32.8 & 33.5 & 33.1 & 0.748 & 215 & 101 & 0.00 \\
\hline 2 & 30 & 16.2 & 15.8 & 15.4 & 13.7 & 33 & 0.703 & 214 & 102 & 0.80 \\
\hline 3 & 60 & 6.3 & 10.2 & 9.1 & 3 & 32.9 & 0.671 & 213 & 100 & 0.91 \\
\hline 4 & 90 & 1.4 & 7 & 6.8 & 1 & 32.8 & 0.650 & 215 & 98 & 0.89 \\
\hline 5 & 120 & -1.3 & 4.8 & 4.9 & $-1,2$ & 32.5 & 0.640 & 220 & 84 & 1.60 \\
\hline 6 & 150 & -2.7 & 3.7 & 4.1 & $-3,1$ & 33.4 & 0.623 & 217 & 88 & 1.41 \\
\hline 7 & 180 & -3.6 & 2.7 & 3 & -5.1 & 32.7 & 0.620 & 213 & 78 & 1.51 \\
\hline 8 & 210 & -4.3 & 2 & 2.6 & -6.6 & 32.6 & 0.607 & 215 & 80 & 1.41 \\
\hline 9 & 240 & -4.5 & 1.9 & 2.4 & -7.5 & 32.9 & 0.605 & 214 & 78 & 1.40 \\
\hline 10 & 270 & -5.1 & 1.3 & 2 & -8.8 & 33 & 0.603 & 214 & 78 & 1.39 \\
\hline 11 & 300 & -5.5 & 0.9 & 1.7 & -9.8 & 32.5 & 0.605 & 215 & 78 & 1.35 \\
\hline
\end{tabular}


In table 1 and table 2 above could seen that rate decline temperature air in cabin refrigerator for second type refrigerator tested take place in a manner proportional together with time testing. In refrigerator $\mathrm{A}$ is visible achievements minimum temperature in 5 times clock testing on the cabin above $-11.8{ }^{\circ} \mathrm{C}$, middle cabin $-6.2{ }^{\circ} \mathrm{C}$, cabin below $-5.1{ }^{\circ} \mathrm{C}$ and temperature product $-9.8{ }^{\circ} \mathrm{C}$. Average input power for A refrigerator is 83.3 Watts and input power inside condition stable is 66 Watts, EER 1.84. While for refrigerator B performance minimum temperature in 5 hours time testing on the cabin above $-5.5^{\circ} \mathrm{C}$, cabin middle $-0.9^{\circ} \mathrm{C}$, cabin below $1.7{ }^{\circ} \mathrm{C}$ and temperature product $-9.8^{\circ} \mathrm{C}$. average input power is $85.8 \mathrm{~W}$ atts and input power inside condition stable is 74 Watts, EER 1.64.

Figure 2 shows chart relationship between rate decline temperature in cabin refrigerator and product to time testing for A refrigerator. The graph is also visible that initially decline temperature rather fast, after hose time certain decline temperature take place rather slow and inclined stable. In refrigerator A is visible achievements temperature minimum enough low, meaning show off cooling system work on the refrigerator very good. In figure 3 it is also seen usage power and voltage electricity for time testing. Voltage electricity coming in to A refrigerator is enough stable range between 210 and 220 volts. Power the electricity used by a refrigerator A first enough big that is range 130 Watts and so on after the A refrigerator system is stable power used enough small around 70 Watts. Average input power required refrigerator is around 83.3 Watt.

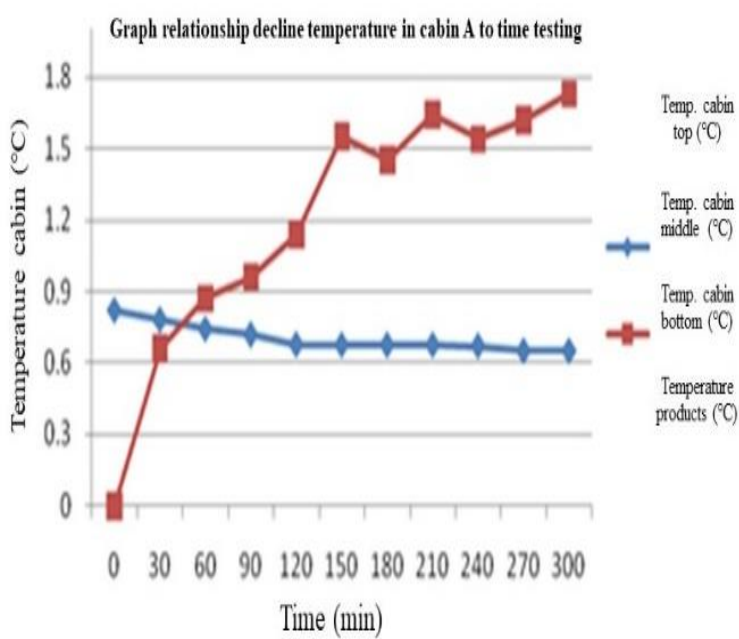

Figure 2 : Graph relationship decline temperature in cabin to time testing

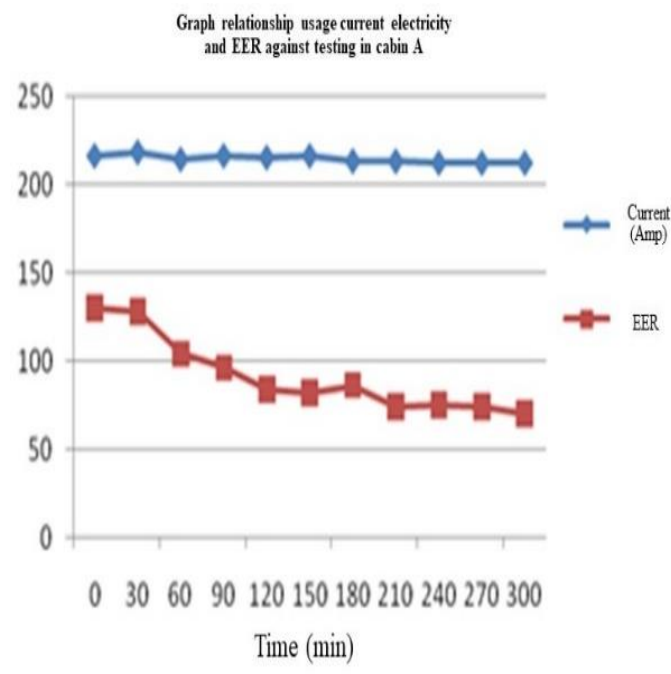

Figure 4 : Graph relationship usage current electricity and EER against testing

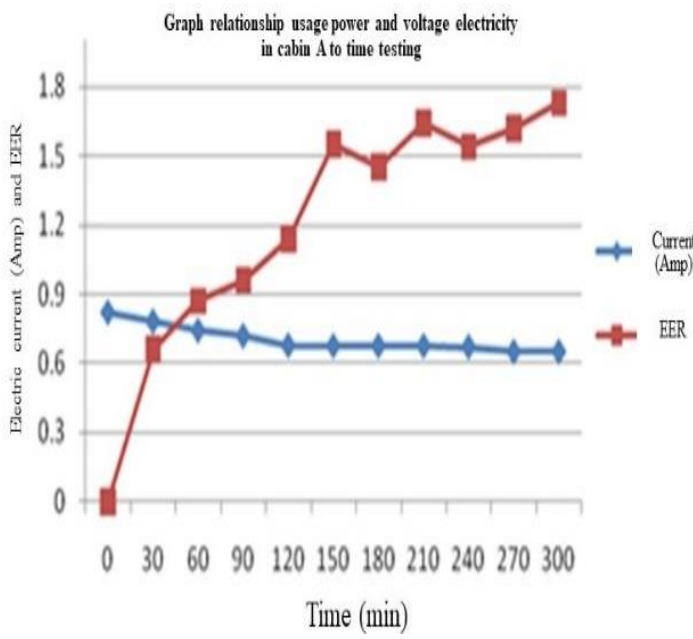

Figure 3 : Graph relationship usage power and voltage electricity to time

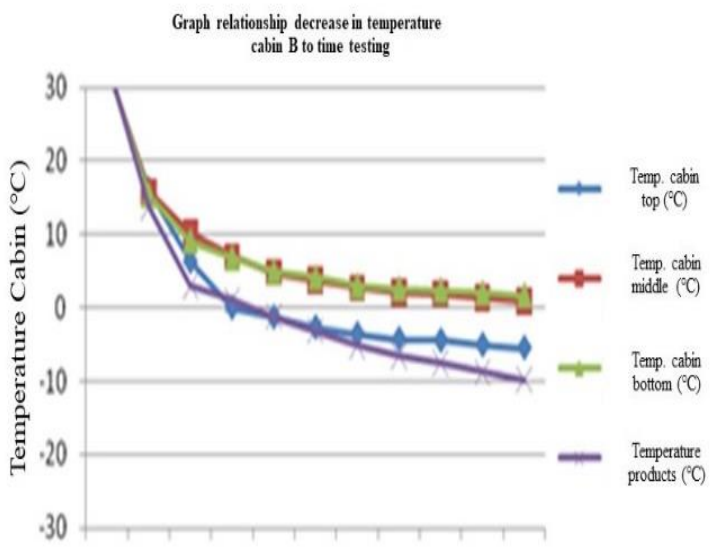

$0 \quad 306090120150180210240270300$

Time (min)

Figure 5 : Graph relationship decrease in temperature cabin to time testing 
In figure 7 , it can be seen current the electricity used by a refrigerator ranges from 0.605 to $0.748 \mathrm{~A}$. Numbers this relatively smaller compared to current electricity needed by a refrigerator that is around 0.65 to $0.82 \mathrm{~A}$. Where as EER seen tend to rise up to can reach 1.60. Data results testing two the brand refrigerator (A and $\mathrm{B}$ ) to its performance parameters that is input power required, performance minimum temperature and EER seen that second the brand refrigerator have sufficient performance parameters well However thus refrigerator A has work parameters a little more well compared to refrigerator B.

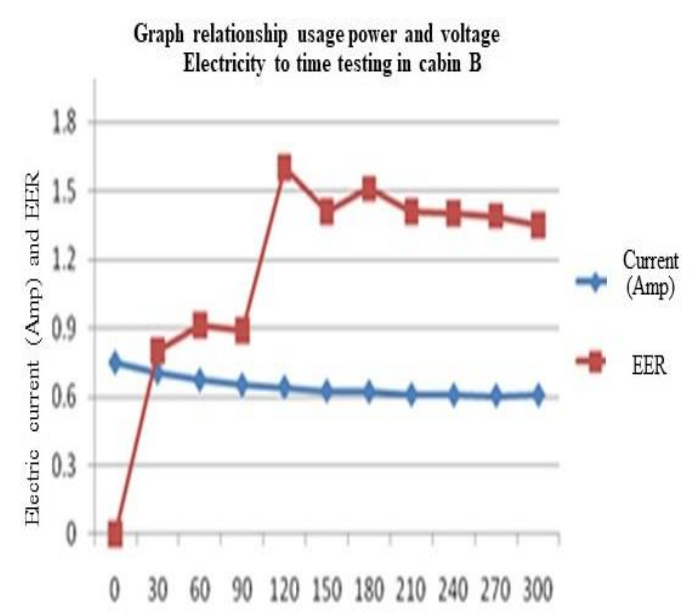

Time (min)

Figure 6 : Graph relationship usage power and voltage electricity to time testing

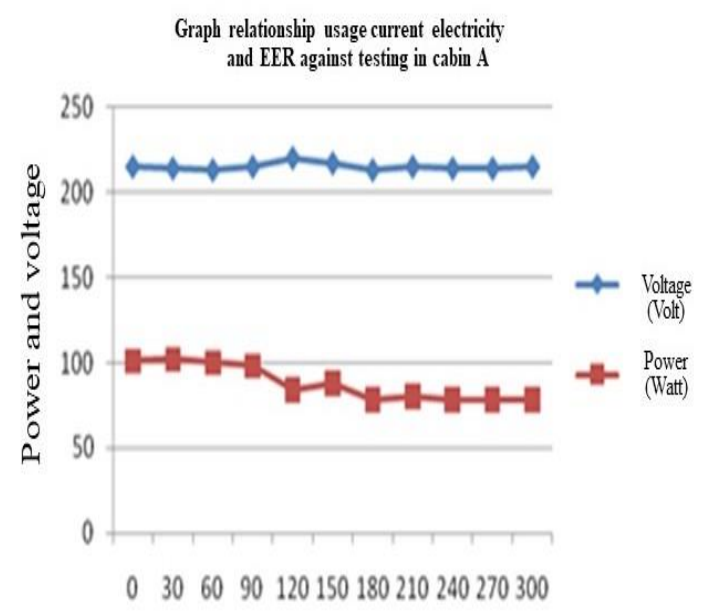

Time (min)

Figure 7 : Graph relationship usage current electricity and EER against testing

\section{CONCLUSION}

From the results testing stunned the performance two the brand refrigerator that is refrigerator A and refrigerator $\mathrm{B}$, can concluded:

1. Performance second the brand A refrigerator and $\mathrm{B}$ fridge are enough well, this seen from achievements minimum temperature in the cabin on for refrigerator $\mathrm{A}$ and $\mathrm{B}$ are $-11.8^{\circ} \mathrm{C}$ and $-5.5^{\circ} \mathrm{C}$; $-6.2{ }^{\circ} \mathrm{C}$ and $0.9^{\circ} \mathrm{C}$ in the cabin center and $-5.1^{\circ} \mathrm{C}$ and $1.7{ }^{\circ} \mathrm{C}$ in the cabin bottom, temperature product is $-14.4{ }^{\circ} \mathrm{C}$ and $-9.8^{\circ} \mathrm{C}$.

2. Average input power A refrigerator is ${ }_{\mathrm{EER}} \mathrm{Natts}$ and 85.8 Watts for refrigerator $\mathrm{B}$.

3. Maximum Energy Efficiency Ratio ( $\mathrm{L}_{\text {LEx }}$, or second refrigerator is 1.73 for refrigerator A and 1.60 for refrigerator $\mathrm{B}$.

4. Based on performance parameters the refrigerator is tested, then could A relative refrigerator have the performance better compared to refrigerator B.

\section{ACKNOWLEDGEMENTS}

This research was supported by Department of Mechanical Engineering.

\section{REFERENCES}

[1] Andersen, SA. Automatic Refrigeration. Denmark: MacLaren \& Sons LTD, Danfoss, Nordborg. 1959.

[2] Arismunandar, W. Air Refresher. Jakarta: Pradnya Paramita. 1986.

[3] Arora, CP. Refrigerating and Air Conditioning. Second Edition. New York: McGraw-Hill Book Company Inc. 2001.

[4] ASHRAE Handbook. Refrigerating and Air Conditioning Engineers. Fundamental Volume. Georgia: American Society of Heating Atlanta. 1977.

[5] ASHRAE Handbook. CD Version 1996-1999.

[6] BS EN. 153:1990. European Standard EN 153. British Standars Institution; 1990.

[7] Carrier Handbook. Air Conditioning System Design. New York: McGraw-Hill Book Company Inc. 1982. 
[8] Darmanto, PS., I Made Astina. Development of the Prototype of Stationary Air Conditioning Machines (Mobile AC Units). Competitive Grant Research Report VI / 2. 1992

[9] Dossat, Roy J. Principles of Refrigeration. Second Edition. New York: John Wiley \& Sons. 1981.

[10] Rustandi, et al. Report Testing Efficiency Energy Home Electricity Utilizers Stairs. Bandung: Polban; 2003.

[11] Stocker, WF. Refrigeration and Air Conditioning. New York: McGraw-Hil 1 Book Company Inc. 1996: 1996-1999.

[12] International Standard Organization. 7371-1985. International Organization for Standards at zation. Switzerland: ISO copyright office; 1985. 